\title{
Nosocomial infections and risk factors in intensive care unit of a university hospital
}

\author{
Bir üniversite hastanesi yoğun bakım ünitesindeki hastane enfeksiyonları ve risk faktörleri
}

Zuhal Yesilbağ ${ }^{1}$, Asli Karadeniz ${ }^{1}$, Seniha Başaran², Fatih Öner Kaya ${ }^{3}$

\begin{abstract}
Objective: The aim of this study is to evaluate nosocomial infections (NIs) in intensive care unit (ICU) in terms of site of infection, distribution of pathogens and risk factors for developing infection.

Methods: 80 patients staying for more than 48 hours in the ICU were included in the study. Epidemiologic characteristics of the patients, invasive procedures and other risk factors were noted. Cultures, identification of isolates and antibiotic susceptibility tests were made by standard microbiologic methods.
\end{abstract}

Results: Of 56 patients who have developed NIs, 26 $(50 \%)$ had pneumonia, 15 (28.8\%) had bloodstream infections and $6(11.5 \%)$ had urinary tract infections. Klebsiella pneumoniae (23.5\%), Pseudomonas aeruginosa (19.6\%), and Acinetobacter spp. (15.6\%) were the most frequently isolated microorganisms, respectively. For Klebsiella pneumoniae isolates, extended spectrum beta lactamase (ESBL) rate was $91.6 \%$, carbapenem resistance rate was $15.6 \%$ and for Pseudomonas aeruginosa and Acinetobacter spp. carbapenem resistance rates were $60 \%$ and $100 \%$ respectively. Hemodialysis, enteral nutrition, total parenteral nutrition and prolonged hospitalization for more than 10 days were determined as independent risk factors for developing NI. Additionally Acute Physiology and Chronic Health Evaluation (APACHE) II score, length of ICU stay and lenght of hospital stay before ICU were found to be high in the NI group.

Conclusion: Pneumonia is the most common $\mathrm{NI}$ and carbapenem resistance in Gram-negative bacilli was remarkably high in our ICU. It was considered that infection control measures must be applied carefully, invasive procedures should be used in correct indications and we should avoid long-term hospitalization if unnecessary. $J$ Clin Exp Invest 2015; 6 (3): 233-239

Key words: Intensive care unit, nosocomial infections, carbapenem resistance

\section{ÖZET}

Amaç: Bu çalışmada yoğun bakım ünitesindeki (YBÜ) hastane enfeksiyonlarının (HE) enfeksiyon odağı, patojenlerin dağılımı ve risk faktörleri açısından değerlendirilmesi amaçlandı.

Yöntemler: YBÜ'de 48 saatten fazla kalan 80 hasta çaışmaya dahil edildi. Hastaların epidemiyolojik özellikleri, invaziv girişimler ve diğer risk faktörleri kaydedildi. Kültürler, patojenlerin tanımlanması ve antibiyotik duyarlılık testleri standart mikrobiyolojik yöntemlerle yapıldı.

Bulgular: HE gelişen 56 hastanın 26 (\%50)'sında pnömoni, 15 (\%28,8)'inde kan dolaşımı enfeksiyonu ve 6 (\%11.5)'sında üriner sistem enfeksiyonu saptandı. Klebsiella pneumoniae (\%23.5), Pseudomonas aeruginosa $(\% 19,6)$ ve Acinetobacter spp. $(\% 15,6)$ sırasıyla en sık saptanan etken mikroorganizmalar idi. Klebsiella pneumoniae izolatlarında genişlemiş spektrumlu beta laktamaz (GSBL) oranı \%91,6, karbapenem direnci \%15,6, Pseudomonas aeruginosa ve Acinetobacter spp. izolatları için de karbapenem direnci sırasıyla $\% 60$ ve $\% 100$ olarak saptandı. Hemodiyaliz, enteral beslenme, total parenteral beslenme, 10 günden uzun süreli yatış $\mathrm{HE}$ gelişimi açısından bağımsız risk faktörleri olarak saptandı. "Acute Physiology and Chronic Health Evaluation" (APACHE) II skoru, YBÜ'de yatış süresi ve YBÜ öncesi hastanede yatış süresi de $\mathrm{HE}$ gelişen grupta daha yüksek bulundu.

Sonuç: Hastanemiz YBÜ'de pnömoni en sık görülen HE olarak saptandı ve Gram-negatif basillerdeki karbapenem direnci dikkat çekici ölçüde yüksek bulundu. Enfeksiyon kontrol önlemlerinin dikkatli bir şekilde uygulanması, invaziv girişimlerin doğru endikasyonlarda uygulanması ve gereksiz uzun dönem yatışlardan kaçınılması gerektiği düşünüldü.

Anahtar kelimeler: Yoğun bakım ünitesi, hastane enfeksiyonları, karbapenem direnci

\footnotetext{
${ }^{1}$ Maltepe University Faculty of Medicine, Department of Infectious Diseases and Clinical Microbiology, Istanbul, Turkey

${ }^{2}$ Istanbul University Istanbul Faculty of Medicine, Department of Infectious Diseases and Clinical Microbiology Istanbul, Turkey ${ }^{3}$ Maltepe University Faculty of Medicine, Department of Internal Medicine, Istanbul, Turkey
}

Correspondence: Zuhal Yesilbağ,

Maltepe Üniv. Tıp Fakültesi, İnfeksiyon Hastalıkları ve Klinik Mikrobiyoloji AD, Istanbul, Turkey Email: zuhalyes@gmail.com 


\section{INTRODUCTION}

Nosocomial infection ( $\mathrm{NI}$ ) is defined as an infection which is not in the incubation period at the time of admitting to hospital and develops after 48 hours of hospital admission, within 3 days of discharge or 30 days of an operation. These infections cause high mortality and morbidity rates, prolonged hospitalization and high financial burden. Patients in intensive care units (ICUs) are only $10 \%$ of all hospitalized patients, but they account for approximately $25 \%$ of all Nls, and it has been reported that $45 \%$ of all nosocomial bacteremia and pneumonia are seen in ICUs [1,2]. In this study, it was aimed to evaluate NIs in ICU in terms of site of infection, distribution of causative pathogens and their antibiotic susceptibility pattern and the risk factors for developing infection.

\section{METHODS}

This prospective study has been conducted in the ICU of Istanbul University Istanbul Faculty of Medicine between March-August 2010 after the study has been approved by the ethics committee. 80 patients over 18 years of age who had stayed more than 48 hours in our ICU were included in the study. The patients who were not followed up from the first day of admission to ICU were excluded. If there was a unit where patients stayed for more than 24 hours before our ICU, these were recorded as internal units, surgical units, emergency unit and units/ICUs of other hospitals.

Epidemiological variables such as age, gender, diagnosis at admission, invasive procedures such as surgical intervention, central vascular line, urinary catheter, nasogastric tube, enteral nutrition, and risk factors such as disease severity at the time of admission (Acute Physiology and Chronic Health Evaluation II [APACHE II] scores), underlying diseases, exposure to antibiotics, duration of hospitalization, and immunosupression were recorded. Patients were followed up in terms of developing NIs and causative pathogens during the hospitalization period. NIs were defined according to CDC (Centers for Disease Control and Prevention) definitions [3].

Clinic samples were taken from the sites of infections. Catheter samples were inoculated on sheep blood agar, sputum, endotracheal aspirates (ETA), pus, bile and various body fluid samples were inoculated on sheep blood agar and MacConkey agar, urine samples were inoculated on sheep blood agar and "eosin methylene blue" (EMB) agar. Isolated bacteria were identified with conventional microbiological methods, and antibiotic susceptibility tests were performed with Kirby-Bauer disc diffusion technique. Extended spectrum $\beta$-lactamase (ESBL) producing was shown with double disc synergy test. Blood cultures were performed with BacT/ ALERT (bioMérieux, Durham, North Carolina, USA) automatization system.

For statistical evaluation, "Statistical Package for Social Sciences" SPSS 15.0 program was used. Chi-square test, Mann-Whitney $U$ test and logistic regression analysis tests were used. All $p$ values $\leq 0.05$ were considered as significant.

\section{RESULTS}

A total of 80 patients who were hospitalized in ICU were evaluated during the study period. Of the 80 patients, $46(57.5 \%)$ were male, and $34(42.5 \%)$ were female. The median age was $57.43 \pm 16.50$ (23-90) years. Of the 80 patients, 19 (23.8\%) were hospitalized in surgical units, $13(16.3)$ were hospitalized in internal units, $33(41.3 \%)$ were hospitalized in emergency unit and $15(18.8 \%)$ were hospitalized in other hospitals before admitting to our ICU. The median duration of hospitalization in other units before ICU was $6.58 \pm 11.74$ (0-80) days. The median duration of hospitalization in our ICU was 28.79 \pm 21.29 (4-90) days.

During the follow up, Nls were developed in 52 $(65 \%)$ patients. Among these patients, $26(50 \%)$ of them had pneumonia, $15(28.8 \%)$ of them had bloodstream infections, $6(11.5 \%)$ of them had urinary tract infections (UTIs), 2 (3.8\%) of them had surgical site infections, $2(3.8 \%)$ of them had intraabdominal infections, and $1(1.9 \%)$ of them had skin and soft tissue infection. In two patients who had pneumonia and 2 patients who had bloodstream infections, the pathogen could not be isolated and considered as "clinically-defined pneumonia" and "clinical sepsis". Also in one patient who had surgical site infection, the pathogen could not be isolated. Gram-negative bacilli were the most common causative pathogens isolated in the patients who had Nls. Klebsiella pneumoniae was the most frequent pathogen, and Pseudomonas aeruginosa, Acinetobacter spp, and Escherichia coli followed respectively (Table 1). Vancomycin-resistant enterococci (VRE) had been isolated in $11.7 \%$ of the patients who had NIs and it was the most common pathogen among Grampositive cocci (Table 1). Fifty seven percent of E.coli isolates were ESBL-positive. $91.6 \%$ of Klebsiella pneumoniae isolates were ESBL-positive and 4 $(36.3 \%)$ of them were carbapenem-resistant also. 
Table 1. Causative microorganisms in the patients with nosocomial infections

\begin{tabular}{lcc}
\hline Microorganisms & $\mathbf{n}$ & $\mathbf{( \% )}$ \\
\hline Klebsiella pneumoniae & 12 & $(23.5)$ \\
Pseudomonas aeruginosa & 10 & $(19.6)$ \\
Acinetobacter spp. & 8 & $(15.6)$ \\
Escherichia coli & 7 & $(13.7)$ \\
Vancomycin-resistant enterococci & 6 & $(11.7)$ \\
Candida spp. & 3 & $(5.8)$ \\
Methicilin-resistant Staphylococcus aureus & 2 & $(4.0)$ \\
Methicilin-resistant coagulase & 1 & $(2.0)$ \\
negative staphylococcus & 1 & $(2.0)$ \\
Enterobacter spp. & 1 & $(2.0)$ \\
Serratia marcescens & &
\end{tabular}

Univariate analysis of risk factors for developing NIs revealed that central vascular line, urinary catheter, nasogastric tube, drainage catheter, mechanic ventilation, enteral nutrition, total parenteral nutrition (TPN), hemodialysis, $\mathrm{H} 2$ receptor antagonist/proton pomp inhibitor (PPI) exposure during hospitalization, prolonged hospitalization for more than 10 days and antibiotic exposure in last 3 months were significant factors (Table 2).

Multivariate analysis of these factors showed that hemodialysis, enteral nutrition, TPN and prolonged hospitalization for more than 10 days were independent risk factors (Table 3). Among continuous variables APACHE II score, length of stay in ICU and length of stay in other units before ICU were found to be significantly high in the patients with NIs (Table 4).
Table 2. Univariate analysis of effects of invasive procedures and risk factors on development of nosocomial infections

\begin{tabular}{|c|c|c|c|}
\hline & $\begin{array}{l}\text { Patients with } \\
\text { Nls }(n=52)\end{array}$ & $\begin{array}{c}\text { Patients without } \\
\text { NIs }(n=28)\end{array}$ & $\mathbf{p}$ \\
\hline & n (\%) & n (\%) & \\
\hline \multicolumn{4}{|l|}{ Risk factors } \\
\hline Diabetes mellitus & $14(26.9)$ & $6(21.4)$ & 0.78 \\
\hline Renal failure & $20(38.4)$ & $7(25.0)$ & 0.32 \\
\hline Hepatic failure & $2(3.8)$ & $1(3.6)$ & 1.00 \\
\hline Heart failure & $2(3.8)$ & $2(7.1)$ & 0.60 \\
\hline History of myocardial infarction & $10(19.2)$ & $6(21.4)$ & 1.00 \\
\hline Chronic obstructive lung disease & $6(11.5)$ & $2(7.1)$ & 0.70 \\
\hline Malignancy & $14(26.9)$ & $6(21.4)$ & 0.78 \\
\hline Transplantation & $2(3.8)$ & $1(3.6)$ & 1.00 \\
\hline Immunosupression & $2(3.8)$ & $2(7.1)$ & 0.60 \\
\hline Immunosupressive therapy & $2(3.8)$ & $3(10.7)$ & 0.33 \\
\hline Advanced age (>65 yaş) & $20(38.5)$ & $10(35.7)$ & 1.00 \\
\hline Prolonged hospitalization (>10 gün) & $44(84.6)$ & $14(50.0)$ & $<0.001$ \\
\hline \multicolumn{4}{|l|}{ Exposure to antibiotics } \\
\hline Last 3 months & $35(67.3)$ & $12(42.9)$ & 0.05 \\
\hline Last 6 months & $41(78.8)$ & $17(60.7)$ & 0.11 \\
\hline Last 1 year & $45(86.5)$ & $19(67.9)$ & 0.07 \\
\hline \multicolumn{4}{|l|}{ Invasive procedures } \\
\hline Surgical implementation & $21(40.4)$ & $6(21.4)$ & 0.13 \\
\hline Central vascular line & $50(96.2)$ & $18(64.3)$ & $<0.001$ \\
\hline Urinary catheter & $52(100)$ & $20(71.4)$ & $<0.001$ \\
\hline Nasogastric catheter & $46(88.5)$ & $14(50.0)$ & $<0.001$ \\
\hline Mechanic ventilation & $50(96.2)$ & $16(57.1)$ & $<0.001$ \\
\hline Drainage catheter & $26(50.0)$ & $7(25.0)$ & 0.03 \\
\hline Hemodialysis & $22(42.3)$ & $4(14.3)$ & 0.01 \\
\hline Enteral nutrition & $47(90.4)$ & $13(47.4)$ & $<0.001$ \\
\hline Total parenteral nutrition & $20(38.5)$ & $3(10.7)$ & 0.01 \\
\hline $\mathrm{H}_{2}$ receptor antagonist/PPI received & $52(100)$ & $24(85.7)$ & 0.01 \\
\hline
\end{tabular}

NI: Nosocomial infection, PPI: Proton pomp inhibitor 
Table 3. Multivariate analysis of effects of risk factors and invasive procedures on development of nosocomial infections

\begin{tabular}{lccc}
\hline & $\begin{array}{c}\text { Patients with } \\
\text { NIs }(\mathbf{n = 5 2 )}\end{array}$ & $\begin{array}{c}\text { Patients without } \\
\text { NIs (n=28) }\end{array}$ & p \\
\cline { 2 - 3 } & $\mathbf{n}(\%)$ & $\mathbf{n}(\%)$ & \\
\hline Prolonged hospitalization (>10 days) & $44(18.0)$ & $14(56.7)$ & 0.01 \\
Hemodialysis & $22(20.0)$ & $4(43.3)$ & 0.05 \\
Enteral nutrition & $47(90.4)$ & $13(47.4)$ & 0.04 \\
TPN & $20(38.5)$ & $3(10.7)$ & 0.05 \\
\hline
\end{tabular}

NI: Nosocomial infection, TPN: Total parenteral nutrition

Table 4. Effects of continuous variables on development of nosocomial infections

\begin{tabular}{lcccc}
\hline & $\begin{array}{c}\text { Patients with } \\
\text { NIs }(\mathbf{n = 5 2})\end{array}$ & $\begin{array}{c}\text { Patients without } \\
\text { NIs (n=28) }\end{array}$ & p \\
\cline { 2 - 3 } & Mean \pm SD & Mean \pm SD & \\
\hline Age & $57.5 \pm 16.8$ & $57.1 \pm 16.0$ & 0.91 \\
APACHE II & $21.3 \pm 6.82$ & $12.7 \pm 7.9$ & $<0.001$ \\
Length of ICU stay (day) & $36.1 \pm 21.49$ & $15.2 \pm 12.6$ & $<0.001$ \\
Stay in other units before ICU (day) & $8.6 \pm 13.5$ & $2.8 \pm 5.9$ & $<0.001$ \\
\hline
\end{tabular}

SD: Standard deviation, APACHE: Acute physiology and chronic health evaluation, ICU: Intensive care unit, NI: Nosocomial infection

\section{DISCUSSION}

Since Nls have high mortality, morbidity rates and financial burden, and may be partially prevented with basic implementations, it has became an important health problem within the recent 30 years. In our country, dimension of infections was investigated and precautions were taken by surveillance programs for prevention and control of NIs in many hospitals in recent 10 years. The most important point in follow-up of patients staying in ICU is prevention of NIs as well as treatment of their primary diseases.

"The European Prevalence of Infection in Intensive Care" (EPIC) working group conducted a study in 1417 ICUs from 17 countries in 1992 and determined the rate of NIs as $24.7 \%$ [4]. After 15 years from this study, EPIC II which was a point prevalence study has been conducted, and the rate of infections in 1265 ICUs from 75 countries was found as $51 \%$. However, unlike the previous study the rate of all infections was reported as $51 \%$ in EPIC II study, differentiation of community-acquired infections and NIs was not performed [5]. In Brazil, Oliveira et al. reported the infection rate in ICU as 20.3\%; and in a study conducted in China between 2003-2007 NIs rate was reported as $26.8 \%[6,7]$. In our country, infection rates in ICUs differed from centre to centre and were found in a wide range such as $5.3-65.3 \%[8,9]$. Erol et al. reported the rate of NIs in ICU as 53.5\%, Palabıyıkoglu et al. reported as $95.7 \%$ and Çelik et al. reported as $72 \%[9,10,11]$. In spite of these high rates, in the study conducted by Arslan et al. rate of NIs in internal and surgical ICUs was reported as $5.3 \%$ [12]. In a study conducted by Willke et al. it was reported that ICUs were the units where NIs were most frequently seen $(30 \%$ $64.6 \%$ ) for 7 years [13]. In our study, Nls developed in $65 \%$ of 80 patients.

In majority of studies, the most commonly reported sites of nosocomial infections in ICUs are respiratory and urinary tracts. Pneumonia is the most frequent $(50 \%) \mathrm{NI}$ in our ICU, consistent with many studies that performed in our country and also in the world [5,14-17]. Then, the most frequent infections were found as bloodstream infections $(28.8 \%)$, UTIs $(11.5 \%)$, surgical site infections $(3.8 \%)$, intraabdominal infections (3.8\%) and skin and soft tissue infections $(1.9 \%)$, respectively. Most studies report that Gram-negative bacteria are the most common cause of NIs in ICU $[5,17]$. In our study, K.pneumoniae was the most common pathogen (23.5\%), followed by P.aeruginosa (19.6\%), Acinetobacter spp. (15.6\%) and E.coli (13.7\%) respectively. According to the results of studies conducted in our country; Çelik et al. and Erbay et al. reported that P.aeruginosa and Staphylococcus aureus, Tüfek et al. reported that Acinetobacter spp. and P.aeruginosa were the most common pathogens 
respectively $[11,16,18]$. In a cross-sectional study conducted in hospitals located in Aegean region, Acinetobacter spp. and S.aureus were reported as the most common pathogens [19]. Enterobacteriaceae (notably E.coli, K.pneumoniae), S.aureus and $P$.aeruginosa were reported as the most common pathogens in EPIC study [4]. In our study, frequency of $S$.aureus infections have been found as $4 \%$, relatively low compared with the other studies. Furthermore, it is extremely remarkable that VRE had been found at a rate of $11.7 \%$ and it was the most common pathogen among Gram-positive cocci. It was found that carbapenem resistance is quite high in Gram-negative bacilli. $60 \%$ of $P$.aeruginosa species, $33.3 \%$ of K.pneumoniae species and $100 \%$ of Acinetobacter species were resistant to carbapenem. In a study conducted in the ICUs of a training and research hospital, Bilman et al. reported carbapenem resistance rates as $85 \%$ (meropenem) and $87 \%$ (imipenem) for Acinetobacter spp. and, 35\% (meropenem) and $36 \%$ (imipenem) for P.aeruginosa [20]. In another study conducted by Yolbaş et al. carbapenem resistance rate for Acinetobacter spp. was reported as $87 \%$ [21]. In our study, $100 \%$ resistance to carbapenem for Acinetobacter species suggest us a clonal spread, and also it constitutes an evidence for increasing carbapenem resistance in every year in Acinetobacter spp.

While various invasive procedures such as mechanical ventilation, central vascular line, TPN, urinary catheter, hemodialysis, surgical intervention applied in ICUs are important for survival of patients, they are risk factors for development of Nls since they may be an entrance for the causative microorganisms. In a retrospective study in which Ding et al. evaluated the NIs in ICU between 2003-2007, they found that $3 / 4$ of patients with pneumonia had tracheotomy or mechanical ventilation, more than half of the patients with USI and bloodstream infections had urinary catheter and intravenous catheter before the development of infections [7]. It was reported that NIs are correlated with invasive procedures in many other studies $[22,23]$. In univariate analysis, use of mechanical ventilation, hemodialysis, central vascular line, urinary catheter, nasogastric catheter, drainage catheter, enteral nutrition, TPN, H2 receptor antagonist/PPI exposure were found significantly higher in the group with NIs (Table 2). When logistic regression analysis was applied in these variables; it was seen that hemodialysis, enteral nutrition and TPN were the independent risk factors for development of Nls (Table 3). It was previously shown that gastric colonization increased as a result of dilution of gastric content by enteral nutrition and increasing of $\mathrm{pH}$ [24]. In various studies, it was shown that enteral nutrition increases gastroesophageal reflux and risk of aspiration, and aspiration is a major risk factor for development of pneumonia $[25,26]$. In our study, enteral nutrition was found as one of the independent variables increasing development of NIs.

In various studies it has been reported that patients who are below the age of 1 and above the age of 60 are at increased risk for development of Nls $[2,27]$. Brawley et al. found that risk for development of infections increases with age [28]. In our study, no statistically significant correlation was found between development of NIs and age. APACHE II scoring system which is used for evaluating the severity of acute disease, is known as having a good correlation with mortality and development of NIs. Akkus et al. observed that patients whose APACHE II score is higher than 15 , are at increased risk for development of NIs [29]. However, several studies have determined that APACHE II score is not an independent risk factor for development of NIs $[30,31]$. In our study APACHE II score was found as $21.3 \pm 6.8$ in the patients with Nls and $12.7 \pm 7.9$ in the patients without NIs, difference between two groups was statistically significant (Table 4). Patients in ICUs are exposed to many invasive procedures and, are at increased risk for development of NIs associated with prolonged hospitalization. It was seen that lenght of ICU stay is significantly higher in the patients with NIs in our study, consistent with the other studies conducted in our country [8,31-33]. In several studies also conducted in United States and Europe, it was shown that there is a significant correlation between length of ICU stay and development of NIs [5,6,22,34]. We had determined that $63.5 \%$ of patients with NIs $(33 / 52)$ had a history of hospitalization in other units before the ICU stay and when compared with the group without NIs, this finding was statistically significant. Also, it was seen that length of stay in other units before ICU is significantly longer in the group with NIs compared with the group without NIs (Table 4).

In conclusion, it was seen that the most frequently encountered $\mathrm{NI}$ was pneumonia in our ICU, followed by bloodstream infections and UTIs. Klebsiella pneumoniae, Pseudomonas aeruginosa and Acinetobacter spp. were found as the most frequent causative microorganisms, respectively. VRE was found the most common pathogen among Grampositive cocci, and all of the Acinetobacter species were found to be resistant to carbapenems. It was determined that high APACHE II score, prolonged 
hospitalization in ICU, prolonged hospitalization in other units before ICU, hemodialysis, enteral nutrition and TPN are independent risk factors for development of Nls. It was considered that each hospital should apply infection control measures by determining own causative microorganisms, antibiotic resistance patterns and risk factors with regular surveillance cultures and should apply invasive procedures in correct indications.

\section{REFERENCES}

1. Trilla A. Epidemiology of nosocomial infections in adult intensive care units. Intensive Care Med 1994;20:1-4.

2. Fridkin SK, Welbel SF, Weinstein RA. Magnitude and prevention of nosocomial infections in the intensive care unit. Infect Dis Clin North Am 1997;11:479-496.

3. Garner JS, Jarwis WR, Emori TG, et al. CDC definitions for nosocomial infections. Am J Infect Control 1988;16:128-140

4. Vincent JL, Bihari DJ, Suter PM, et al. The prevalence of nosocomial infection in intensive care units in Europe. Results of the European Prevalence of Infection in Intensive Care (EPIC) Study. EPIC International Advisory Committee. JAMA 1995;274:639-644.

5. Vincent JL, Rello J, Marshall J, et al. International study of the prevalence and outcomes of infection in intensive care units. JAMA 2009;302:2323-2329.

6. Oliveira AC, Kovner CT, Silva RS. Nosocomial infection in an intensive care unit in a Brazilian University Hospital. Rev Latino-Am Enfermagem 2010;18:233-239.

7. Ding JG, Sun QF, Li KC, et al. Retrospective analysis of nosocomial infections in the intensive care unit of a tertiary hospital in China during 2003 and 2007. BMC Infect Dis 2009;9:115-121.

8. Buke C, Sipahi OR, Tasbakan M, et al. The evaluation of the infections developing in intensive care unit of the internal medicine department. Turk J Infect 2005;19:67-73.

9. Erol S, Kürsat H, Özkurt Z, et al. Nosocomial infections in our reanimation unit. Hastane İnfeksiyonları Dergisi 2000;4:97-100.

10. Palabiyikoglu I, Tulunay M, Oral M, Bengisun JS. Nosocomial infections observed in a reanimation unit: risk factors, causative agents and antimicrobial resistance. Hastane İnfeksiyonları Dergisi 2000;4:150-155.

11. Celik I, Inci N, Denk A, et al. Prevalence of hospital acquired infections in anesthesiology intensive care unit. Fırat Tıp Derg 2005;10:132-135.

12. Arslan H, Gurdogan K. Nosocomial Infections Detected in Intensive Care Units. Hastane İnfeksiyonları Dergisi 1999;3:165-170.

13. Willke A, Baskan S, Palabiyikoglu I, et al. Hospital infections observed in Ibn-i Sina Hospital Between 1992-1998. Hastane İnfeksiyonları Dergisi 2001;5:3137.
14. Meric M, Wilke A, Caglayan C, Toker K. Intensive care unit-acquired infections: Incidence, risk factors and associated mortality in a Turkish university hospital. Jpn J Infect Dis 2005;58:297-302.

15. Esen S, Leblebicioglu H. Prevalence of nosocomial infections at intensive care units in Turkey: a multicentre 1-day point prevalence study. Scand J Infect Dis 2004;36:144-148.

16. Erbay H, Yalcin AN, Serin S, et al. Nosocomial infections in intensive care unit in a Turkish university hospital: a 2-year survey. Intensive Care Med 2003;29:1482-1488.

17. Dasgupta S, Das S, Chawan NS, Hazra A. Nosocomial infections in the intensive care unit: Incidence, risk factors, outcome and associated pathogens in a public tertiary teaching hospital of Eastern India. Indian J Crit Care Med 2015;19:14-20.

18. Tüfek A, Tekin R, Dal $T$, et al. Evaluation of hospital infections developing in intensive care unit during a decade and reviewof literature. Dicle Med J 2012;39:492-498.

19. Avci M, Genc V, Ozgenc O, et al. Infections in intensive care units in the aegean region: a cross-sectional investigation. Turk J Infect 2009;23:157-161.

20. Bilman FB, Ayaydın Z, Turhanoğlu M, et al. Nonfermentative gram-negative microorganisms isolated from intensive care units and their resistance profiles in a training and research hospital. J Clin Exp Invest 2014;5:391-396.

21. Yolbaş I, Tekin R, Gunes A, et al. Antibiotic susceptibility of Acinetobacter baumannii strains in a university hospital. J Clin Exp Invest 2013;4:318-321.

22. Rosenthal VD, Guzman S, Orellano PW. Nosocomial infections in medical-surgical intensive care units in Argentina: attributable motality and lenght of stay. Am J Infect Control 2003;31:291-295.

23. Edwards JR, Peterson KD, Andrus ML, et al. National Healthcare Safety Network (NHSN) Report, data summary for 2006, issued June 2007. Am J Infect Control 2006;35:290-301.

24. Jacobs S, Chang RWS, Lee B, Barlett FW. Continuous enteral feeding: A major cause of pneumonia among ventilated intensive care unit patients. J Parent Enteral Nutr 1990;14:353-356.

25. Metheny NA, Clouse RE, Chang YH, et al. Tracheobronchial aspiration of gastric contents in critically ill tube-fed patients: frequency, outcomes, and risk factors. Crit Care Med 2006;34:1007-1015.

26. Kadamani I, Itani M, Zahran E, Taha N. Incidence of aspiration and gastrointestinal complications in critically ill patients using continuous versus bolus infusion of enteral nutrition: A pseudo-randomised controlled trial. Aust Crit Care. 2014;27:188-193.

27. Korten V. Hastane infeksiyonlarının epidemiyolojisi ve genel risk faktörleri. In: Akalın $\mathrm{H}$, eds. Hastane İnfeksiyonları. 1th edn. Ankara: Güneş Kitabevi, 1993;34-44. 
28. Brawley RL, Weber DJ, Samsa GP, Rutala WA. Multiple nosocomial infections: An incidence study. Am J Epidemiol 1989;130:769-780.

29. Akkus N, Biberoglu K, Tarhan O. Risk factors of the infections in intensive care units: Experience in Dokuz Eylul University Faculty of Medicine. Hastane İnfeksiyonları Dergisi 1997;1:101-105.

30. Craven DE, Kunches LM, Lichtenberg DA, et al. Nosocomial infection and fatality in medical and surgical intensive care unit patients. Arch Intern Med 1988;148:1161-1168.

31. Aygen B, Kayabas U, Guven M, et al. Surveillance of hospital infection in the ICU in Erciyes University Hos- pital: Epidemiology, risk and prognostic factors. Yoğun Bakım Dergisi 2001;1:122-130.

32. Canbaz S, Peksen Y, Leblebicioglu H, et al. Evaluation of nosocomial infections in intensive care unit. $J$ Exp Clin Med 2000;17:149-155.

33. Ak O, Batirel A, Ozer S, Colakoglu S. Nosocomial infections and risk factors in the intensive care unit of a teaching and research hospital: A prospective cohort study. Med Sci Monit 2011;17:29-34.

34. Orsi GB, Scorzolini L, Franchi C, et al. Denditti M. Hospital-acquired infection surveillance in a neurosurgical intensive care unit. J Hosp Infect 2006;64:23-29. 